\title{
Prioritization of factors affecting the safety of sport facilities in Kermanshah Based on AHP
}

\author{
Bahieh Zarei ${ }^{1}$, Kheidan Hatami $^{2}$, Zahra Keshtmand ${ }^{3}$ \\ $1 \mathrm{PhD}$ student, Department of Sport Management, Sanandaj Branch, Islamic Azad University, Sanandaj, Iran \\ 2 Assistant Professor, Department of Sport Management, Sanandaj Branch, Islamic Azad University, Sanandaj, Iran. E-mail: \\ kiamak_2001@yahoo.com \\ 3 PhD student, Department of Sport Management, Sanandaj Branch, Islamic Azad University, Sanandaj, Iran
}

\begin{abstract}
This prioritize the factors affecting the safety of sport facilities based on AHP model is examined. This research strategy in terms of quantity and type AHP, in terms of sectional, both practical and in terms of gathering data is the type of field. The study was based questionnaire measurement elite views were set. In order to test the hypothesis-of a comparison test was used categories together. The Expert Choice software was used in this study. The findings obtained showed that 27 items in 5 categories are involved in determining the safety of sporting venues. On this basis and according to safety experts, sports facilities and sports equipment is the most important component of the Earth's surface. 0.320 is the significance of these items. Management factors weighing $0.268,0.182$ weight room equipment, first aid dressing and platform weighing 0.134 and 0.094 in second weight with the audience. The results showed that the use of safe floors, the use of qualified instructors, the use of appropriate sports flooring, installing warning signs in the hall and regular periodic visits to the salon equipment coefficients $0.070,0.059,0.052,0.049$ and 0.047 of the most important items in the factors affecting the safety of the sport.
\end{abstract}

Keywords: safety, sport facilities, AHP.

\section{INTRODUCTION}

Inclusive sport as a social phenomenon is considered the best mechanism for providing social health and mental health. Linking countries and enhance mutual understanding and peaceful coexistence between the peoples of other important achievements is that through sports attention to political and cultural arena of income governments and communities. Exercise also contributed to national productivity and ensures an enormous impact on GDP respectively. Physical exercise and training in our country's nascent field, which is still almost traditionally are placed. Although modify the field has been created, but to achieve global standards by Distance there are many. Facilities and sport facilities are no exception and the qualitatively and quantitatively, to access conventional international standards, has a long way to go. Although an exact places after the Islamic Revolution in manufacturing and construction has been significant action sports spaces. However, there are still many shortcomings (MOZAFFARI, 2008).

One of the important issues surrounding sport places, its safety (BAKER ET AL., 2014). The issue of safety in all circumstances referred to in the exercise of injury, organizers and audience members on the ground and prevent the holding space. (ASKARIAN, 2011). One of the principal concern of safe- 
ty has always been a sport places. Because due to the occurrence of many events in the sport injuries and stop-work (Sauer, 2007). And not the optimal amount of a deterrent factor is the participation in sports comes to (AKBARIA INSURANCE SALES, 2010). The quality and quantity of the exercises, competitions and athletic competition and the development of sport in our society has a direct impact. So sports experts' science about the components before these are variable. But it comes to the sport places that are considered less sensitive and Safety them is undesirable (FARSI, 2006). So the lack of safety at football match between the national football teams of Iran and Japan in the spring of 2005 resulted in seven people died and dozens were injured (ASKARI, 2011).

It must be admitted that the safety and security of sport places difficult, complex and time taking, but undoubtedly correct and logical predictions that can be done efficiently. The participants and spectators to minimize risks and injuring. And researchers come to special areas of sports management and sports facilities as well as the importance of this issue and in recent years has sought to this issue. And measurement and evaluations in the field of data have.

Such research can be to research Rich (200), Persian and colleagues (2006); Baker et al (2014), Akbarian Insurance Sales (2010); Donalson et al (2013); Paulus and Donalson (2015) and ... cited.

The targeted and timely and accurate decisions in terms of safety because it can have a significant impact on the security of holding sports events. The need for a powerful technique that can help people in this area is the perfectly sensible.
One of the most efficient techniques, is the Analytic Hierarchy Process. The first was introduced in 1980 by Thomas L. This technique is based on a couple comparisons established to study various scenarios gives managers (KASPERSKY; KENIKEL, 2004). The growing tendency of people to exercise their understanding of the role of sport in promoting physical and mental health of human beings. Regular participation in physical activities in a secure environment multiple benefits physically, mentally and emotionally for teens and young adults as well as many opportunities to enjoy new experiences and emotions, physical activity, enhance skills, social interaction and objectives related to personal development will create for them. People who participate in activities that doesn't have experience physical pleasure and enjoy physically and will be healthier (RAMEZANI; NAZARIAN MADAVANI, 2013). Thus, in the construction of new sports facilities in the country, the authorities should try considering the cost of construction of sport facilities, places of which is in accordance with international standards.

The attention to safety is the most important sport facilities, because of the time Word users to these places until leaving them the task of protecting the health and safety of the users of these sites will be the responsibility of the directors and officers (AKBARIAN INSURANCE SALES, 2010).

The important thing in terms of safety is how we can use this tool for growth and development of all aspects of the sport to be in conformity with international standards. Unknown factors affecting safety and sports spaces, lead managers and organizers of sports programs doesn't guide (PARKS; BIVERLY, 2004). The allocation of 
appropriate facilities and in accordance with the standards necessary to promote the sport. However, the immune status of spaces and sport facilities as Standard show that these areas do not have adequate safety (FARSI, 2006). In order to equip sport places and meet existing standards safety Sports spaces is an inevitable necessity.

Overall comprehensive studies about the safety of sport facilities can be a good solution to solve the problems of these places offer. We can also hope that the immune status of sport facilities to be closer to minimum standards. For this study analysis in research-earlier levels of sport hierarchy are unwelcome in the security space will be used.

The aim of this research is to prioritize the factors affecting sport facilities in Kermanshah based on hierarchical analysis.

\section{LITERATURE}

Petridv et al (2002) lands on the immunity status of the game and the amount of damages paid in the country of Greece research. The results showed that the lack of safety in the construction lands him play well worn and non-standard equipment, they were the cause of most important of injuries.

Cassidy and Yantrob (2002) reported that in 2002 in different states of America, 1037 by the National Union of Consumers America's playground caps were reviewed to determine their immune status. The study on the risk factors that lead to injury and death they had been focused users. Some of the results are as follows:

- Surfaces: 75 percent of the land in 1037 that were studied were lacking adequate levels of these statistics in 2000, 80 per cent. Having appropriate surfaces in the lands of the game is the most important factor in safety because 80 percent of sports damages caused by falling on unsuitable surfaces were created.

- Stands: 27 percent of the 1037 lands do not play well positioned for the audience and the lack of safety in the construction of stands one of the most important factors were identified is audience injury.

- Failure to adhere to walls and fences around the game lands are standard: $36 \%$ of the lands studied the game, away from walls and fences surrounding lands very close to the playground to play, and they are not met standard that it causes damages athletes was hard and even death.

Equipment used: Fortunately, 86 percent of the lands studied games use the standard equipment appropriate exercise.

Zazyrin et al (2003) in a study that aims to study security policies of football clubs was concluded that 100 percent of the country's football clubs have qualified coaches and first aid professionals. Then, as it became clear that the required financial loss, lack of awareness of managers and employees of safety and improper structure of the main reasons Football Stadiumsecurity policy enforcement are football clubs in Australia.

Marshall, Loomis and Waller (2005) in a study entitled Assessing Protective equipment used in rugby and its role in preventing sports injuries, conclude that Use appropriate protective equipment can prevent the onset of many sports injuries. Hotsky Jackson and Kent (2006) in a study of risk management in universities in the United States of America football stadium was examined and found that more than 70 percent of football stadiums to apply risk man- 
agement operations.

Hall et al (2007) in a study entitled audience understanding of security management at NASCAR races showed that 52 percent of fans said they do not play them any concern about security. And the results showed that only 47 percent of the audience knew that in a race where and how to look for emergency care.

Miller et al (2008) A study of the understanding of the audience of the Super Cup security after the September 11 attacks to the conclusion that further stadiums, security matters, especially not observe the entrance. As a result, one of the ways to increase the safety of the use of surveillance cameras in and around the stadium to cite population control. The majority of respondents in this study believed that private sanctum of them not to body searches and not using CCTV cameras will not be compromised.

Finch et al (2011) research on safety barriers at the national level to facilitate their review. The results showed that for the purpose of research should be implemented prevention programs, infrastructure and facilities needed to be provided and the conditions related to the safety analysis.

Merlos, Hampton and Manu (2011) conducted research into the safety and sports stadiums. The results showed that the safety risk posed by the audience standing, falling chairs, guard rails and denial of access to emergency negatively affect the safety of spectator's degree.

Buck, Johnson and Tympka (2012) in a study aimed at investigating the role of health programs and policies that promote safety to the aforementioned programs can be concluded that the effectiveness of safety practices in areas increase sports.
Ibrahim et al (2015) research on the determinants of security at the venue of sports events discussed in Eilat Kavra. The aim of this study formed by audience. The results showed that the availability of security tools significantly improve security sports attention venue has no effect. In addition, the availability of security personnel and crowd behavior has no negative impact on security.

\section{RESEARCH METHODOLOGY}

The research strategically bit, in terms of execution path descriptive analytic hierarchy in terms of cross sectional time was as field data collection and the purpose.

The study population

\section{Statistical sample and sampling}

The sample in this study population were considered and 15 times or manager of a sport facilities were purposefully selected and questionnaires completed the study.

\section{Variables}

In this study, the role of variables into 5 main categories and 27 sub categories were divided or items that continue to exist addressed them.

Courts and fitness equipment, including the use of appropriate sports flooring, the flooring of high quality, the use of safety flooring, repairing damaged surfaces for children's playgrounds, a suitable buffer along the ground, using old equipment and using standard equipment.

First aid: presence of fire in the hall, the first aid box in the hall, near the sports hall to hall and easy access to emergency medical facilities.

Technical equipment for the hall: subject to dangerous levels of insulation, insulation suitable power wires, cooling and heating 
equipment in the right place, the right lighting Hall, contrast color at different levels of fire alarm systems and emergency lighting system

Cloakroom and platform audience: included in the Surveillance, the floors right in the dressing room and grandstand, the appropriate stands, install guards right in front of the grandstand, placement of escape from fire rigs audience and emergency exit staircase.

Management factors: subject, the use of qualified teachers, lack of awareness of managers and staff safety tips, warning signs installed in the hall, regular periodic visits to the salon equipment, banning athletes in unconventional sites, survey reports from the coaches, the separation of different age ranges, times of exercises and activities, formulation of trusted applications repairs.

\section{Measuring Tools}

Statistical analysis plan

A couple of fuzzy numbers were used to compare the options that were on the whole not worth the value-laden.

\section{RESULTS}

\subsection{Qualitative research findings}

Study and theoretical study helped the researchers to identify factors affecting the safety of interviews with experts in the areas of sport to discuss broader vision. The main component of the study were five components as follows. Components that form as a guide to interviews qualitative study was carried out.
Figure 1: Factors affecting the safety of sports facilities

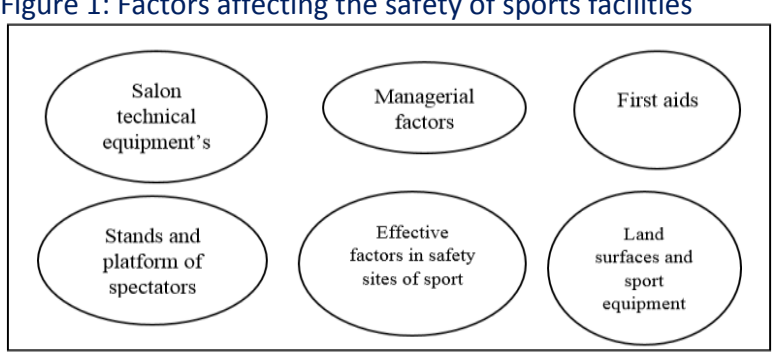

\subsection{The results of a study}

After collecting the opinions of 15 experts in the field the final decision matrix was formed in the following table:

Table 1: Matrix combines paired comparisons of criteria

\begin{tabular}{|c|c|c|c|c|c|}
\hline & A & B & C & D & E \\
\hline A & 1 & $2 / 704200$ & $1 / 398812$ & $1 / 319508$ & $3 / 380430$ \\
\hline B & $0 / 369795$ & 1 & $0 / 685552$ & $0 / 544123$ & $1 / 593046$ \\
\hline C & $0 / 714892$ & $1 / 458678$ & 1 & $0 / 606254$ & $1 / 586602$ \\
\hline D & $0 / 757858$ & $1 / 837819$ & $1 / 649473$ & 1 & $3 / 084568$ \\
\hline E & $0 / 295820$ & $0 / 627728$ & $0 / 630277$ & $0 / 324194$ & 1 \\
\hline
\end{tabular}

Figure 2: Ranking of Factors affecting the safety of sport facilities

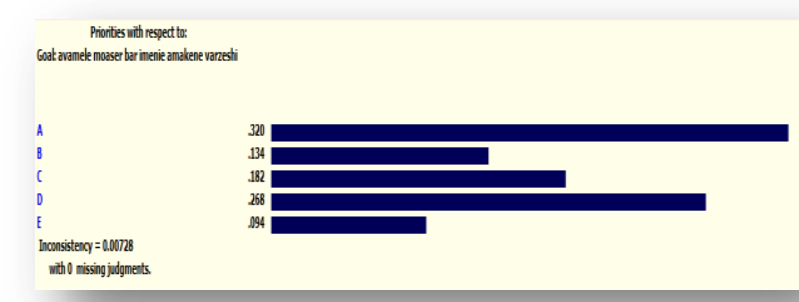

Software compatibility matrix composite output rate based on 0.007 , respectively, due to the fact that less than 1.0, there is little conflict. The chart above shows the analytic hierarchy process weight components. On this basis and according to safety experts, sports facilities and sports equipment is the most important component of the Earth's surface. 0.320 is the significance of these items. The above analysis shows the management factors weighing 0.268, 0.182 weight room equipment, first aid 
dressing and platform weighing 134.0 and 0.094 in second weight with the audience.

Figure 3: Weight and overall rating of items

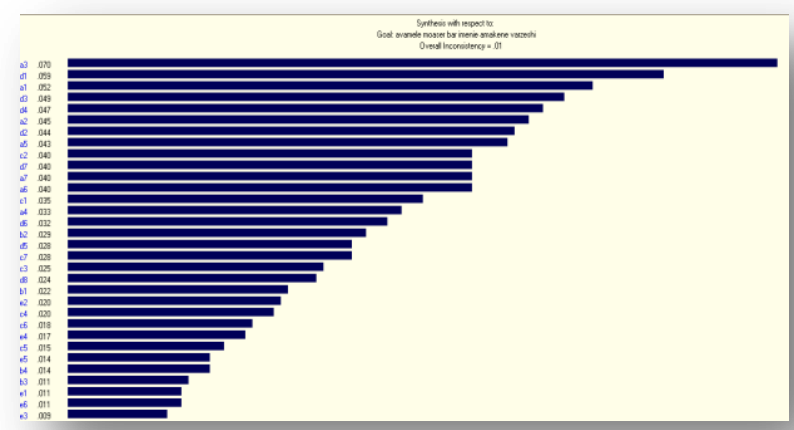

Software compatibility matrix composite rate based on the output of 0.01 , respectively, due to the fact that less than 1.0, there is little conflict.

$0.070,0.059,0.052,0.049$ and 0.047 of the most important items in the factors affecting the safety of the sport.

\section{CONCLUSION}

One of the principal concern of safety has always been a sport places. Because due to the occurrence of many events in the sport injuries and prevent screw (SAUER, 2007). And not the optimal amount of factors, it comes to preventing participation in sports is. The quality and quantity of the exercises, competitions and athletic competition and the development of sport in our society has a direct impact. So experts of sports science of predicting the variable components are concerned. But it comes to the sport places that are considered less sensitive and Safety them is undesirable (FARSI, 2006). Therefore, in this study the antecedent's safety and general priorities were examined.
Based on the evidence obtained, it was determined that the safety of sporting venues are influenced by many factors that are more important or indeed Intra-group variance safety sport facilities is an explanation by them. This topics include management factors, ground and sports equipment, first aid, technical equipment hall, a cloakroom and platform is the audience. Having appropriate levels in the lands of the game is the most important factor in safety lands because 80 percent of injury-sports were created as a result of falling on unsuitable surfaces. And the conditions related to safety analysis, it is consistent. And then AHP weight showed courts and fitness equipment items, safe use of coatings by a factor of 0.217 is the most important factor in this category. Among components of different departments Places exist indoor sports flooring any importance of special importance to the point that the design, construction, implementation and maintenance of indoor sports flooring Salons, has become a specialty. This led to the emergence of specialized companies in the world of sports flooring is sent. The Company, its products are presented in accordance with existing standards and marketing efforts on standards and indicators than from scientific production, to persuade their customers. Many gyms, for various social events and gatherings such as festivals, special events and seminars are used to take the floor must be proportional to the user types the desired durability and good resistance and easy cleaning maintainable. Fall athletes and flooring inappropriate this Salon is the major cause of sports injuries, consonants. The most important factor in this category, and then install warning signs in the hall, regular periodic visits to the salon 
equipment and Ranks followed. Inappropriate stadiums tactics of the most important factors of the implementation of security policies at the club-soccer countries are Australia, consonants. 0.181 And 0.152 are next in rank. This result is partly the result of Merlos, Hampton and Manu (2011) reported that the safety risk posed by the audience standing, falling chairs, guard rails and denial of access to emergency negatively affect the safety of spectators degree, is consistent.

Injuries and accidents are inevitable in sports and athletes are always exposed to some potential risks, which in the case of the mechanism of injury and how to treat these injuries, the athlete will be reduced next disabled. Find stems. And finally AHP weight room equipment items showed dangerous levels by a factor of 0.219 the most important factor was the right and proper insulation electrical wire system, emergency lighting, refrigeration and thermal equipment perfect location, perfect lighting hall, the fire alarm system and contrast color at different levels by a factor of $0.192,0.153,0.137,0.112,0.099$ and 0.085 were next in rank.

In general, due to the increase in young human resources and Taking into account the other segments of the country, their needs and health (physical and mental) and leisure, to engage in sport activities that meet this need, next year has been approved by the legal authorities, and holding international sporting events in the various disciplines of the ground, introduced by our country in various fields in the world makes possible.

It is clear in this regard and deep respect and responsibly to build a significant amount of sports facilities, The existence of sport facilities and safety standards for the protection of athletes' health, promote skills and optimal display them during training, exercises and competitions (internal and external) is essential. For this study the laws and regulations of various sporting disciplines in sport lands standard safety conditions in terms of size, equipment and other physical factors such as light, heat, air circulation and coordination and technical and engineering services to bring activities them with the standard of sport - recreational sport facilities construction is very important.

\section{Suggestions for future researches}

The study considered only sport facilities in Tehran contract, so it is suggested that future researchers do research in other areas so as to better explain the results.

Afterwards the study had a different socio-economic conditions is suggested to be involved in the factors affecting the safety of these agents. In relation to safety in this research in the factors affecting safety in a hierarchy is set up, it is suggested in the discussion of quantitative analysis and structural equation model to be tested.

\section{REFERENCES}

AKBARIAN SHORKAEI, FATEMEH. (2010). Determine the immune status of sport facilities in Mazandaran province. Master's thesis, Faculty of Physical Education and Sport Sciences, University of Mazandaran.

BACKE, S., JANSON, S., \& TIMPKA, T. (2012). Governance and implementation of sports safety practices by municipal offices in Swedish communities. Int J Inj Contr Saf Promot, 19(2), 163-169. http://doi.org/10. 1080/17457300.2011.635212.

BEKKER, S., WHITE, P., DONALDSON, A., 
COOK, J., GABBE, B., LLOYD, D., \& FINCH, C. (2014). What is the role of key sports safety agencies in the development and dissemination of sport safety policies for community sport settings? British Journal of Sports Medicine, 48(7), 565-566. http://doi.org/ 10.1136/bjsports-2014-093494.17.

CASSADY, A.WEINTRAUB, R. (2002). PLAYING IT SAFE. The ConsumerFederation of America: U.S. Public Interest Research Group Education.

DONALDSON, A., BORYS, D., \& FINCH, C. F. (2013). Understanding safety management system applicability in community sport. Safety Science, 60, 95-104. http://doi.org/10.1016/j.ssci.2013.06.007.

FINCH, C. F., GABBE, B. J., LLOYD, D. G., COOK, J., YOUNG, W., NICHOLSON, M., DOYLE, T. L. A. (2011). Towards a national sports safety strategy: addressing facilitators and barriers towards safety guideline uptake. Injury Prevention: Journal of the International Society for Child and Adolescent Injury Prevention, 17(3), e4. http://doi.org/10.1136/ip.2010.032006.

HALL, S., MARCIANI, L., COOPER, W. E., \& ROLEN, R. (2007). Securing collegiate sport stadiums in the 21st century: Think security, enhance safety.

HWANG, C. L., \& YOON, K. (2012). Multiple attribute decision making: methods and applications a state-of-the-art survey (Vol. 186). Springer Science \& Business Media.

IBRAHIM, T. O., OJO, A. V., IBRAHIM, M. O., \& IBRAHIM, T. (2015). Factors determining sport venue security at the Kara state stadium complex Ilorin, kwara state. Ilorin Journal of Education, (34), 65-74.

KASPERCZYK, N., \& KNICKEL, K. (2004). AnaIytic hierarchy process (AHP). IVM Institute, 1-6. Retrieved from http://www.ivm.vu.nl/ en/Images/MCA3_tcm53-161529.pdf.
LHOTSKY, G. J., JACKSON, E., \& KENT, A. (2006). An analysis of risk management at NCAA division IA Football stadiums.

LIPTON, E. (2005). US report lists possibilities for terrorist attacks and likely toll. New York Times, 16.

MELROSE, A., HAMPTON, P., \& MANU, P. (2011). Safety at sports stadia. In Procedia Engineering (Vol. 14, pp. 2205-2211). http://doi.org/10.1016/j.proeng.2011.07.27 7.

Merriman, J. H. Conn, J. (1988).Sport Law: A Social Perspective. Journal of Sport and Social Issues; $12 ; 9$

Mozafri, Seyed Amir Ahmad (2009), management of sports facilities and sites, publications Faculty of Physical Education and Sport Sciences, Tarbiat Moallem University of Tehran.

PERSIAN, AR. (2006). "The safety situation at Tehran University sport facilities and provide appropriate solutions" project, Institute of Physical Education and Sport Sciences.

PETRIDO, E SIBERT, J . DEDOUKOU, $X$. SKALKIDIS, I .TRICHOPOULOS, D... (2002). Injuries in public and private playgrounds: the relative contribution of structural, equipment and human factors. ActaPaediatr

PETRIDO, E SIBERT, J. DEDOUKOU, $X$. SKALKIDIS, I .TRICHOPOULOS, D... (2002). Injuries in public and private playgrounds: the relative contribution of structural, equipment and human factors. ActaPaediat PHELAN, KJ. KHOURY, J. KALKWARF, HJ. LANPHEAR, BP. (2001). Trends and patterns of playground injuries in United States children and adolescents. Ambulatory Pediatrics.

POULOS, R. G., \& DONALDSON, A. (2015). Improving the diffusion of safety initiatives 
in community sport. Journal of Science and Medicine in Sport, 18(2), 139-144. http://doi.org/10.1016/j.jsams.2014.01.001 RAMEZANI, ALIREZA; NAZARIAN MADVANY ABBAS. (2013). the relationship between safety and efficiency of facilities and sports from the perspective of students with the prevalence of sports damages. Sports Management Studies, 21, 173-194.

$\mathrm{RICH}$, D. (2000). How to Become a Sport Safe Club: Guidelines for developing and implementing a sport safety plan. Journal of Science and Medicine in Sport, 3(2, Supplement 1), 58-63. Retrieved from http://www.sciencedirect.com/science/arti cle/pii/S1440244000800705.

SAMATAS, M. (2007). Security and Surveillance in the Athens 2004 Olympics: Some Lessons from a Troubled Story. International Criminal Justice Review, 17(3), 220-238. http://doi.org/10.1177/1057567707306649 SAUER, F. (2007). Playing it safe. European Coatings Journal, (7-8), 34-38. http://doi.org/10.5694/mja14.c1103.

SAYARNEZHAD, JIM. (2008). "Evaluate immune status of the premises, facilities and equipment for the province", a research project of the Department of Physical Education in Mazandaran province.

SHOJAEI, VAHIDI.SEDAQTY POUR, N. (2007), principles of supervision in physical education, publications Hafeez, printing.

STACEY, A. SUECOFF, M. JEFFREY, R. (1999). A Comparison of New York City Playground Hazards in High- and Low-Income Areas.

TAYLOR, I. (1991). English football in the 1990s: Taking Hills borough seriously In British Football and Social change - getting EuropeLeicter University pree .pp: 67-69 TICHAAWA, M. T., \& SWART, K. (2009). Cameroonian Fans' Perceptions of the 2010 Fifa World Cup: A Case Study of Buea and
Limbe. Cape Peninsula University of Technology.

VIENEY,CH \& DOG, P. (1997). A risk management framework for the sport and recreation industry. Office of sport and recreation Tasmania.

W MARSHALL, S. LOOMIS, D. E WALLER, A. (2005). Evaluation of protective equipment for - prevention of injuries in rugby union. International Journal of Epidemiology; 34:113-118.

ZAZRYN, T .FINCH, C .GARNHAM, A. (2001). Is safety a priority for football clubs?

ZAZRYN, T. R., FINCH, C. F., \& MCCRORY, P. (2003). A 16 year study of injuries to professional boxers in the state of Victoria, Australia. British journal of sports medicine, 37(4), 321-324.

ZHANG, H., \& YU, L. (2012). MADM method based on cross-entropy and extended TOPSIS with interval-valued intuitionistic fuzzy sets. Knowledge-Based Systems, 30, 115-120.

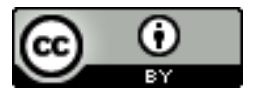
License information: This is an openaccess article distributed under the terms of the Creative Commons Attribution License, which permits unrestricted use, distribution, and reproduction in any medium, provided the original work is properly cited.

Article received on September 08, 2017.

Evaluated September 09, 2017.

Accepted on September 22, 2017.

Published on September 22, 2017.

\section{How cite this article (ABNT):}

ZAREI, Bahieh; HATAMI, Kheidan; KESHTMAND, Zahra. Prioritization of factors affecting the safety of sport facilities in Kermanshah Based on AHP. Estação Científica (UNIFAP), Macapá, v. 7, n. 2, p. 129-137, maio/ago. 2017. 